\title{
JARDINEIROS SEM FLORES - O CUIDAR-CUIDADO COM O ADOLESCENTE NÃO CIDADÃO NA PERSPECTIVA DA CIDADANIA
}

Marisa Correia Hirata*

Este trabalho relata uma práxis de enfermagem com um grupo de adolescentes năo cidadãos que já vivenciaram as ruas da cidade de Salvador, Bahia, como moradia e espaço de luta para a sobrevivência, e que, no momento, participam como bolsistas de um projeto de mútua cooperação entre a UFBa e o Projeto Axé. Apresenta como objetivo o cuidar-cuidado com esses adolescentes na perspectiva da cidadania buscando a operacionalizaçăo através de uma visåo qualitativa e dialética. Teve como ponto de partida pressupostos da autora fundamentados em idéias de muitos outros pesquisadores, e baseou-se num processo de interaçăo com o uso de técnica específica para este grupo - a paquera pedagógica - estendida posteriormente como pesquisa participante. Neste caminhar, desenvolveram-se atividades a nivel individual e de grupo com discussőes e aç̋̋es quanto ao processo de saúde com aderência dos componentes do conceito do cuidado. A cidadania foi discutida nos aspectos civis, politicos e sociais, desnudando o eufemismo das leis e incorporando as subjetividades do Ser ao lado das buscas objetivas e coletivas. Interrelaciona práticas tradicionais de enfermagem e terapéuticas alternativas como as essências florais de Bach e técnicas de relaxamento na perspectiva do autoconhecimento como apoio ao equilibrio de sentimentos e emoçס̃es para a transformação no percurso do adolescer numa sociedade excludente. A avaliaçăo foi encaminhada enquanto processo, perpassando todo o estudo, que captou na fala dos jovens, seus desejos de mudanças e de profissionalizaçăo, e que, no entanto, năo encontraram no convênio UFBa/Axé apoio suficiente de atividades educativas-transformadoras, e sim a repetiçăo de um modelo de trabalho explorador. Pontua, finalmente, aspectos que indicam o potencial de transformaçăo e emancipação do adolescente năo cidadăo através da práxis construida ao longo do trabalho.

* Salvador, 1995, 150p. Dissertação (Mestrado em Enfermagem) - Escola de Enfermagem da Universidade Federal da Bahia Orientador: Prof. Dr. Antônio Dias. 